\title{
The Nationalist Action Party: Representing the State, the Nation or the Nationalists?
}

\section{Alev Çınar \& Burak Arıkan}

To cite this article: Alev Çınar \& Burak Arıkan (2002) The Nationalist Action Party: Representing the State, the Nation or the Nationalists?, Turkish Studies, 3:1, 25-40, DOI: 10.1080/714005706

To link to this article: https://doi.org/10.1080/714005706

Published online: 08 Sep 2010.

Submit your article to this journal ¿

Џll Article views: 403

4 Citing articles: 4 View citing articles 5 


\title{
The Nationalist Action Party: Representing the State, the Nation or the Nationalists?
}

\author{
ALEV ÇINAR and BURAK ARIKAN
}

Milliyetçi Hareket Partisi (Nationalist Action Party-MHP) has managed to keep its name, emblem, main organizational structure and basic ideological premises more or less intact since its establishment in 1969. There was only one brief interruption during the post-1980 coup period, when it went by the name Milliyetçi Çalışma Partisi (Nationalist Work Party-MÇP). This consistency is most probably due to the fact that the MHP has remained the only party on the far right of the ideological spectrum in Turkey.

Even though the MHP started to move towards the center with Devlet Bahçeli's leadership in 1997, it remains the only party in Turkey that spans the range of right-wing nationalist ideologies of racial, ethnic, and cultural varieties. ${ }^{1}$ The extremist tendencies within the party do not currently constitute the majority, nor are these views reflected in the party program. However, the MHP harbors such extremist groups, thereby remaining the only option for political formations of the far right.

This essay examines the MHP's ideological and organizational structure. It is argued that the MHP's version of nationalism is predicated on an ambiguous definition oscillating between a cultural and an ethnic definition of the nation. It becomes difficult, if not impossible, to situate the MHP in any one particular position on the spectrum of nationalist ideologies. This ambiguity seems to serve the MHP well, allowing it to take milder positions and put on a more moderate face when the situation requires, appealing to the center-right electorate, and to take on more extremist stances when it wants to appeal to more radical nationalist demands. This flexibility has also allowed the MHP to almost monopolize nationalist positions on the political spectrum and to present itself as the only party that best represents the national interest and not just a particular ideology. It might have been this strategy that brought the MHP the second highest percentage of votes in the 1999 general election. 
Even though the MHP monopolizes the right-wing nationalist end of the political spectrum, the principle identifying the movement is its own version of nationalism referred to as ülkücülük (idealism). This identification dates back to the formation of Ülkü Ocaklarl (Idealist Hearths) in 1968, which were youth organizations formed to fight Communism. Throughout the 1970s, Ülkü Ocaklarl became the most active party group to recruit new members, especially university students, and served as a school where future MHP leaders and activists acquired organizational and leadership skills. Indeed most if not all the current MHP leaders and parliamentarians began their political involvement as members of Ülkü Ocaklarl. However, it should be noted that one off-shoot of Ülkü Ocaklarl were the notorious idealist militant groups, ${ }^{2}$ whose skills of a different (mainly criminal) kind, were acquired during the ülkücü activities of the 1970 s that involved atrocities toward leftist and Marxist groups.

$\ddot{U} l k \ddot{u}$ Ocaklarl also set the tone of the party's ideological basis. Ülkücülük, understood as the ideal of serving one's state, has a slightly different connotation than nationalism. The latter signifies a commitment to the prosperity of a particular community, whereas ülkücülük signifies a devotion to the wellbeing of the state seen as the utmost embodiment of the nation, identifying the state's interests as inseparable from the nation's interests.

\section{HISTORY OF THE MHP}

The first extreme right-wing party of Turkey, Cumhuriyetçi Köylü Millet Partisi (Republican Peasant Farmer's Nation Party-CKMP) was founded in 1948 by General Fevzi Çakmak. At the time Çakmak was the most significant representative of religious nationalistic ideas in Turkey. He was a conservative person recruited because of his name. The party itself was founded by the coalition of small fascist and proto-fascist forces in Turkey. After Osman Bölükbaşı was elected the party chair, it acquired a populist, conservative nationalist stance, which was primarily supported by peasants and the middle classes.

The first party program, valid until the 1960 s, contained a corporatist, developmental-modernist ideology which claimed to restore a proper Kemalist standpoint. The party supported state corporatism believing that this would create an organic, homogenized nation under strict state control. Neither its support base nor the ideology of the party changed until the mid-1960s, and it remained a relatively unpopular party without any significant presence in the political arena. 
In 1965, Alparslan Türkeş was elected as party chair and, with his friends, put Turkist and virulent anti-Communist features into the party rhetoric. Türkeş' Turkism gradually combined Turkish nationalism with Islamic features. During this period the party was in close contact with extreme right organizations such as Türkiye Milliyetçiler Birliği (Turkish Nationalists Union), ${ }^{3}$ Aydınlar Kulübü (Intellectuals Club), Vatansever Türk Teşkilatı (Patriotic Turkish Organization), and Komünizmle Mücadele Dernekleri (Struggle Against Communism Clubs). ${ }^{4}$ These organizations were fascist in their extreme nationalism, rejection of pluralism, and opposition to liberalism, capitalism and Communism. Most of them supported the use of violence against Communists. ${ }^{5}$ The new party ideology adopted in 1967 was primarily shaped by the influences of these organizations. In the party congress of 1967 a new program was accepted based on "communitarian nationalism" and the Dokuz Işı Lights Doctrine). Türkeş was declared Başbuğ (the "great leader"), and coined the well-known statement, "Whoever joins the cause and then becomes a traitor, kill him."

It was not only nationalist ideologies that were turned into a violent political tool in the hands of the MHP, Islam was also politicized as a force that could be manipulated against rising Marxist currents. In the 1970s, Türkeş and his aides referred to Islam as an indispensable part of Turkish culture. This new combination was known as the Turkish-Islamic synthesis (TIS). ${ }^{6}$ Türkeş articulated this synthesis in the following words: "We are as Turkish as the Tengri mountain [located in Central Asia, the place where the MHP believes the Turks' ancestors migrated from], and as Muslim as the Hira mountain [which is located in the Muslim Holy Lands in Saudi Arabia]. Both philosophies are our principles." Within the framework of the TIS, Islam was interpreted as a cultural trait that reinforced Turkish identity. It was also a political strategy since the MHP wanted to mobilize the conservative-religious electorate of central Anatolia in its fight against the revolutionary groups.

These significant changes in ideology advanced the CKMP's transformation into a new political force. In this regard the party's 1969 Adana congress marked a turning point. The name of the party was changed from CKMP to MHP; the rank-and-file Turkists who opposed the Turkish-Islamic synthesis were expelled; and a hierarchical structure that augmented Türkeş' power was institutionalized. The party's anti-capitalist and anti-masonic rhetoric was also jettisoned, making the MHP more acceptable to the establishment as a legitimate force because of its strong anti-Communism sentiment. ${ }^{8}$ 
Still, between 1969 and 1974 the party remained a marginal force in Turkish politics, receiving only three percent of the electoral vote. The party's fortunes changed in 1975 when it was invited to join the Milliyetçi Cephe (Nationalist Front) government with the right-wing Adalet Partisi (Justice Party-AP) and the Islamist Milli Selamet Partisi (National Salvation Party-MSP). The long-divided right realized it was time to unite against the rising power of Bülent Ecevit's Cumhuriyet Halk Partisi (Republican Peoples Party-CHP). Ecevit's popularity was on the rise particularly due to the successful 1974 military intervention in Cyprus, conducted under his premiership.

Although the MHP almost doubled its vote share in the 1977 elections, the party leadership was far from happy. It had hoped the coalition experience would integrate the party into the system as a legitimate actor and broaden its base of support. Even though the party was successful in attracting an increasing number of marginalized middle-class voters who faced difficulties in adapting to the rise of entrepreneurial capitalism, economic hardship, and inflation, the party's inflexible attitude toward change constrained its electoral prospects. Rather than adopting a new strategy and a program that would tackle the problems of the Turkish society, it remained a single-issue party whose only concern was anti-Communist propaganda. Consequently, the MHP failed to gain the support of larger sections of society.

However, before it could evaluate its electoral limitations, the MHP (along with other political parties) was banned as a result of the 1980 military coup. While the left was the army's main target, the MHP was also hard hit by the harsh measures of the intervention. Many MHP supporters and members were given prison sentences. This was a period during which those supporting ülkücüler found themselves having to question their unconditional support of the Turkish state for the first time in their history. A book written by Alparslan Türkeş at the time, entitled Basılan Kervanımı (Our Suppressed Journey) expressed this sense of betrayal by the state. It was also at this time that one of the prominent leaders of the party, Agah Oktay Güner, said "We are in prison, yet our ideology is in government," which became a popular slogan among the ülkücü circles, reflecting their disillusionment and sense of betrayal by the Turkish state.

The period after the military intervention witnessed a further rise of Islam in the ideology of some MHP cadres and supporters, who saw it as a more reliable ideal for devotion than the state and a better answer to their search for identity. This re-orientation towards Islam became the main source of tension within the rank and file of the party, especially when the ülkücü movement entered a revival period as the effects of the military 
coup were winding down. On the other hand, the radical Islamists (who began to support political Islam) were forced to resign from the party. At the time, Türkes was pursuing policies that aimed to make peace with the state forces and to direct the party toward the center of the political spectrum. To achieve these goals, the expulsion of the political Islamist cadres from the party was a necessity since the state in general and the military in particular were extremely sensitive about the rising influence of Islamic fundamentalism. In the 1987 general, and 1991 local, elections the party showed no particular gain at the polls and its performance was almost identical to the pre-1980 period (see Table 1).

TABLE 1

MHP VOTES IN TURKISH ELECTIONS

\begin{tabular}{llll}
\hline & Elections & Votes $(\%)$ & Number of Seats \\
\hline CKMP & 1965 & 2.2 & 11 \\
MHP & 1969 & 3.3 & 1 \\
MHP & 1973 & 3.4 & 3 \\
MHP & 1977 & 6.4 & 16 \\
MÇP & 1987 & 2.9 & - \\
MÇP & $1989^{\mathrm{a}}$ & 4.1 & - \\
MÇP+RP & 1991 & 16.9 & 19 (RP 43) \\
MHP & $1994^{\mathrm{b}}$ & 8 & - \\
MHP & 1995 & 8.6 & - \\
MHP & 1999 & 17.98 & 129 \\
\hline
\end{tabular}

Notes: * Local elections

a Since all pre-1980 political parties were banned from politics by the military junta, the Idealists named their newly founded party as the Nationalist Action Party (Milliyetçi Çalışma Partisi-MÇP).

b In order to pass the national threshold of ten percent, an electoral pact between RP, MHP and a minor third party was formed before the 1991 general elections. Therefore, the results represents neither the electoral strength of the RP nor the MHP alone.

The MHP entered the 1991 elections in a coalition pact with the Islamist Refah Partisi (Welfare Party-RP) in order to circumvent the ten percent threshold restriction, which it could not pass on its own. As a result, the MHP won 19 seats in the parliament. Contrary to the expectations of many, Türkeş was not elected. Parliamentary representation seemed to have been beneficial for the party. In the 1994 local elections its vote share rose to eight percent, and further increased 0.6 percent in the parliamentary elections in 1995. This time, however, the MHP could not enter the parliament due to the election barrier. The party had the potential to pass the threshold, but due to Türkeş' moderate secular policies that primarily aimed to attract the urban electorate, voters in the conservative rural areas were alienated. ${ }^{9}$ It was the RP that won the rural periphery in 1995. 
In 1997, Türkeş died at the age of 80. The ülkücü movement was in shock at the loss of their charismatic leader and faced an uncertain future. Indeed, at the May 1997 party congress, convened only a month after the loss of Türkeş, rivalries surfaced within the party. Eight candidates, including Türkeş' son, Tuğrul Türkeş, ran for party leadership. In the first round, Devlet Bahçeli won the second-highest support from the delegates after Tuğrul Türkeş, but none of the candidates were able to gain the necessary majority.

In the second round, the remaining six candidates withdrew their candidacy and decided to support Bahçeli, which guaranteed certain victory for him. Tuğrul Türkeş, realizing that his chances of winning the congress were minimal, organized a putsch and, with the support of his armed ülkücü militants, invaded the congress and seized the chair. The congress was postponed, but Bahçeli won the leadership when it reconvened in November 1997, opening a new era in the MHP's history.

The election of Bahçeli to the party chair was almost universally approved by party supporters who believed he would reunite the party around its founding principles. There was great enthusiasm toward the MHP in the long-forgotten rural areas. Aware of this potential, Bahçeli and his aides quickly restructured the party's policies and strategies in order to appeal to the expectations of the MHP's electorate in the countryside as well as to its urban supporters. The party core rapidly concentrated its energy to the re-establishment of links with the conservative electorate in central Anatolia. ${ }^{10}$

This strategy was very successful both in rebuilding support in the countryside and in guaranteeing the new leader's control over the party structure. Local branches, which had gained autonomy in previous years due to Türkeş' Kemalist secular policies, were once again brought under the strict control of the core leadership. Those branches that refused to accept party directives were immediately dissolved. The foundation of a party school and a Research and Development Department (RDD) restored the party core's domination and trained members for a fresh approach to politics. Through various publications, including a pamphlet on "How to Behave in Public," "11 the party school educated its members.

As a result, the autocracy of Bahçeli was established, ideological standards were tightened, and links with the rural electorate were strengthened. During this period, which went unnoticed by the mass media, Bahçeli and his aides traveled throughout Turkey (almost 60,000 kilometers by road) listening to the electorate's demands and presenting their ideas on an almost one-to-one basis. As the results of the 1999 general elections revealed, this policy turned out to be very successful (see Table 2). 
TABLE 2

THE RISE OF THE MHP VOTE IN THE COUNTRYSIDE (\%)

\begin{tabular}{lccc}
\hline Traditional Strongholds & 1994 & 1995 & 1999 \\
\hline Amasya & 14.0 & 12.1 & 24.9 \\
Tokat & 12.0 & 12.9 & 29.1 \\
Çorum & 10.8 & 11.5 & 30.0 \\
Çankırı & 20.8 & 18.7 & 38.2 \\
Kayseri & 21.8 & 17.8 & 32.8 \\
Yozgat & 17.4 & 13.9 & 39.8 \\
Aksaray & 14.1 & 14.9 & 35.3 \\
Isparta & 14.4 & 15.7 & 29.3 \\
Kırşehir & 19.3 & 19.9 & 33.6 \\
Erzurum & 18.0 & 14.7 & 26.1 \\
\hline
\end{tabular}

Source: A \& G Research Company.

While the party systematically courted the rural electorate, it was also able to recruit a significant number of academics. This achievement, along with the school and the RDD, raised the party's profile among the urban population, which also increased support for the MHP. Bahçeli's image as a man of integrity who respected the people's aspirations and values was another key factor. Younger people began to consider the MHP as a serious alternative to the other parties. Hence the MHP established a miraculous bridge between the urban nationalist electorate and their rural counterpart. Consequently, the MHP crossed the electoral threshold by a large margin and emerged as the second largest group in the parliament, exceeding even the party leadership's expectations.

\section{NEW TRENDS UNDER DEVLET BAHÇELI'S LEADERSHIP}

As a result, voters' support for the MHP more than doubled between 1995 and 1999. For the first time in its history, the MHP emerged as the secondlargest recipient of votes and became the main partner of the Democratic Left Party (Demokratik Sol Parti-DSP)-MHP-Motherland Party (ANAP) coalition government, with 129 seats in parliament. What was it about Bahçeli's leadership that made such a big difference to the MHP's electoral performance? How was Bahçeli able to bridge the gap between the urban nationalists and rural electorate in such a short period of time?

The most apparent difference between the MHP of Alpaslan Türkeş and that of Bahçeli is the striking contrast of the images each of these two leaders portrayed to the public. While Türkeş came across as a paternalistic and partisan leader, Bahçeli projects the image of a leader who seems to honor the interests of his country over the interests of his party and his personal 
interests. While Türkeş was devoted primarily to ideology, as shown by his expulsion of members who deviated from the party line, Bahçeli makes it very clear that he is primarily devoted to serving the interests of the state, even if these interests may go against particular party policies. This stance was most evident when Bahçeli personally asked one of his popular ministers, Enis Öksüz, to resign from his post as Minister of Transportation in July 2001 when Öksüz's policies regarding the privatization of the stateowned Telecom Company contradicted the coalition government's overall economic recovery program.

Bahçeli repeats his slogan "Önce ülkem, sonra partim, sonra ben" ("first my country, then my party, then myself") at every opportunity. In contrast to Türkeş, who was quoted in a party publication as saying, "Tek hedef Türk için Türk tarafindan" ("The main goal is for the Turk and by the Turk"), Bahçeli appears in the same publication asserting his goal is the wellbeing of "Türkiye" - emphasizing the country at large rather than a particular community. ${ }^{12}$ The difference between a devotion to the Türk as opposed to devotion to Türkiye highlights the crucial difference between the ideological stances of these two leaders.

More importantly, in the eyes of the public, Türkeş was much more closely associated with the ultra-nationalist, militant MHP of the 1970s which was responsible for many killings and atrocities. Whereas Bahçeli, who had an academic background and had served in the party as an educator rather than as militant activist, came across as a much more reliable and trustworthy leader whose claim to clear the MHP of its negative image was taken seriously by the media. Indeed, when Bahçeli announced his new program of renewal emphasizing democracy and human rights, which was approved at the Sixth Congress in November 2000, most popular columnists, even those writing in leftist newspapers, acknowledged his attempt as genuine, even if they thought it unrealistic considering the MHP's past. ${ }^{13}$

Devlet Bahçeli's credibility and the new positive image he brought to the MHP's leadership was not only a result of his academic background or his personal image. Since he replaced Türkeş in 1997, he has shown a consistent devotion to the renewal of the party, which has involved structural changes within party organs and some crucial shifts of emphasis in party ideology, all of which were articulated at the Sixth Congress and brought to life afterwards.

One of the most radical steps was severing ties with the Ülkü Ocaklarl (Idealist Hearths), the party's infamous youth branch. This organization had a reputation of involvement with criminal activity in the 1970s and 
continued covert association with the $\ddot{u} l k \ddot{u} c \ddot{u}$ mafia groups (formed by former members of Ülkü Ocaklarl and believed to have been involved in clandestine operations of the state against the Kurdistan Workers PartyPKK). A new youth organization was formed to start with a clean slate and direct the youth towards artistic and cultural activities rather than political activism. Accordingly, the number of Ülkü Ocaklarl decreased and were brought under the umbrella of a foundation. This was one of the most significant steps toward rebuilding a new and cleaner image for the MHP under Bahçeli.

However, it should be noted that former members of Ülkü Ocaklarl, some of whom have disturbing criminal records, are still active members of the party ranks although they are instructed to keep a low public profile. For example, when party member Yavuz Ceylan, who was convicted of involvement in the murder of Abdi İpekçi (a prominent author and journalist assassinated in 1979), wanted to run for leadership of the Istanbul branch of the party organization, Bahçeli personally asked him to withdraw his candidacy. Bahçeli's concern with public image makes him willing to alienate some groups within the party.

Other related measures that Bahçeli adopted involved the abandonment of several party gestures and other symbols associated with the ülkücü movement. Moustaches running down to the chin, the special ülkücü greeting that involved the banging of each other's heads, refusal to wear ties, wearing of white socks, and other markers of being a "true ülkücü" were all banned. ${ }^{14}$ Indeed, at the Sixth Congress in November 2000, all delegates were wearing ties, none had long moustaches, and there was no extensive head-banging. In contrast to the scandalous congress in May 1997 when Tuğrul Türkeş and his men invaded the hall with guns; this convention took place in utmost discipline, everyone was clean-shaven, appropriately dressed and well behaved as if to defy the image of militancy that had tarnished the MHP for so long. It was certainly a display of Bahçeli's success in having achieved full control over his party and implementing his policy of renewal.

New courses were initiated at the party school. Members and activists, including the parliamentarians, regularly attended classes that included instructions on topics such as dining etiquette, how to greet each other, how to speak in public, and so on. ${ }^{15}$ All of these measures involved the building of a new image for the MHP, one that would sufficiently distance the party from its previous militant image and its association with the ülkücü mafia. 


\section{THE MHP'S IDEOLOGY: REDEFINING NATIONALISM}

The changes the MHP faced with the new leadership were not limited to public image. While the policy changes mentioned above seemed cosmetic, they actually incorporated deeper ideological concerns. The change of leadership in 1997, the unprecedented increase of voter support in 1999 (which even surprised the MHP itself), and its experience as a major coalition partner after this increase, forced the MHP to review its main ideological principles, reinforcing some of the changes that had begun since the last years of Alpaslan Türkeş.

The main ideological tenets of the MHP are built upon the principles of ülkücülük (idealism), nationalism, and the Turkish-Islamic synthesis. While ülkücülük is best translated as idealism, it has a very specific meaning in the Turkish political context which is only used in association with the particular ideological movement that has nourished the MHP. As noted, ülkücülük most accurately means "the love and ideal of serving the state." Indeed, serving the interests of the state is the most fundamental defining cause of the ülkücü movement and the basic ideological tenet of the MHP. Such idealism has been the raison-d'être of the MHP to such an extent that MHP activists did not see any difference between the party and the state, and whoever was the enemy of the state was also deemed the enemy of the party. For this reason, MHP militants believed they fought against all enemies of the Turkish state, be it the Communists and Marxists of the 1970s or the PKK of the 1990s. For this reason, the closure of the MHP after the 1980 coup, and the sentencing of many of its activists, came as a major shock.

However, towards the end of the 1990s, it became increasingly apparent to the MHP circles that the "state" as they understood it may not agree with their ideological principles and that the MHP and the state's official ideology may indeed contradict each other. One of the first signs of this was the Susurluk incident where MHP circles celebrated the notorious victim of a traffic accident, Abdullah Çatlı, as a hero and "true patriot" who died serving his country. An Istanbul delegate of the party, Mehmet Yellice, claimed that Çatli was their fellow idealist and that they respected him. The slogans at the Sixth Congress also declared support for Abdullah Çatl1: "Çatlı is not dead; he lives in our hearts." ${ }^{\prime 6}$ Yet in the eyes of the state (at least officially), Çatlı was nothing more than a cold-blooded criminal, involved in drug dealing, murder, and atrocities.

A second incident that was particularly revealing of the MHP's new approach toward Islam occurred during the oath-taking ceremony at 
parliament just after the April 1999 elections. One party member, Nesrin Ünal, removed her Islamic headscarf before giving her oath. This event facilitated the way for the current coalition partnership of the party.

However, Bahçeli's commitment to adjust the MHP's ideological position toward a more statist and centrist line did not mean that the rest of the party and its supporters would placidly follow. The party's compliance with the state's official position against the Islamic headcovering, as demonstrated by the case of Nesrin Ünal, was met with serious criticism both within the party and from the voters. The MHP was accused of hypocrisy and selling out on a promise made to its electorate. One of the successful slogans used by the party during the 1999 election campaign was "The head-covering issue will be resolved not by cowards but by real men." This slogan targeted voters who had previously supported Refah/Fazilet (Welfare/Virtue) with the hope of reversing the ban on the Islamic head-covering, and were disillusioned with Refah's failure to make any progress on the issue. This compliance not only cost MHP a substantial amount of voter support (see Table 3), but also elicited reaction from within the ranks of the party. On the other hand, that Bahçeli repositioned his party on the head-covering issue in particular, and Islam in general, despite a heavy cost, shows the degree to which he is committed to realigning his party's ideological stance toward a more centrist and statist line.

TABLE 3

ISLAMIC HEAD SCARF ISSUE IN UNIVERSITIES

\begin{tabular}{llllllll}
\hline Party Sympathizers & ANAP & CHP & DYP & DSP & FP & MHP & Other \\
\hline Should be allowed to wear & 39.7 & 18.3 & 76.8 & 18.2 & 99.4 & 96.3 & 75.0 \\
Should take it off & 55.1 & 77.7 & 16.6 & 81.8 & 0.6 & 3.7 & - \\
No idea & 5.1 & 4.1 & 6.6 & - & - & - & 25.0 \\
\hline
\end{tabular}

Source: A \& G Research Company.

The third basic MHP ideological principle is nationalism. Heavily influenced by Aydınlar Ocăg (Hearth of Intellectuals) in the 1970s, the MHP is careful to define Turkish nationalism in terms of "national culture" rather than ethnicity or race. ${ }^{17}$ According to the party, in its narrowest definition, Turkish nationalism is "the love of Turkish nation, and loyalty and service to the Turkish state." 18 In the new program formulated with instructions from Bahçeli and approved at the party Congress in 2000, nationalism is defined as a principle that "forms the basis and the 
mobilizing energy of the social, economic and cultural developments toward making the Turkish Nation ... take its place among the larger community of nations as a powerful, respectable and mighty society."'19 This sense of nationalism implies that citizens' utmost duty is to sacrifice themselves and their interests for the wellbeing of the national community. ${ }^{20}$ For the MHP, devotion to such nationalist ideals is expected not only of its members but from all citizens, regardless of their particular political opinions and preferences. This understanding of nationalism empowered the MHP to impose its ideology as if it is a duty of all Turkish citizens, as illustrated by the slogan that was popular in the 1980s and early 1990s: "Ya sev ya terket" ("love or leave the country").

Katherine Verderey draws attention to two different meanings of nation and nationalism, namely civic and cultural nationalism. In the former case, "nation" is understood as a relationship of citizenship "in which the nation consists of collective sovereignty based in common political participation." "In its second meaning, "nation" is taken as a relation of ethnicity, "in which the nation comprises all those of supposedly common language, history, or broader cultural identity." ${ }^{22}$ As noted, the MHP has become particularly skilled in playing upon the ambiguity between these two meanings of nationalism. The MHP nationalism, with its emphasis on common culture and history, leans more toward a form of cultural nationalism. ${ }^{23}$ However, in several MHP publications, nationalism is even more frequently defined as a love of one's country and loyalty to the state, therefore evoking the other meaning of nationalism that takes it as a relation of citizenship.

Capitalizing on the ambiguity between these two meanings of nationalism, the MHP is able to tap into feelings of patriotism and presents itself as the only party — being the only nationalist party — that represents the true interests of the nation and the state. In other words, this confluence of the two meanings of nationalism allows the MHP to give the impression that representing the national interest is under the monopoly of this one and only nationalist party.

This ambiguity worked to the advantage of the MHP particularly during the 1999 elections, when the electorate had become highly sensitized on issues of patriotism and nationalism in the face of the PKK terrorism and the capturing of the PKK leader Abdullah Öcalan. As a result of demonstrations celebrating the capture of Öcalan headed by the families of soldiers who had died during confrontations with the PKK, sentiments of patriotism and nationalism were running high. This conjuncture allowed the MHP to present itself as the only truly patriotic party owing to its 
nationalism. Coupled with Bahçeli's image as a new leader primarily devoted to the interests of his country rather than his party, this rhetoric must have played a significant role in more than doubling the party's votes. However, some of the voters who had expected the MHP to ensure that Öcalan was hanged were disillusioned when the coalition government, of which the MHP was a member, failed to carry out the death penalty. This was seen as another failure by the MHP to keep its election promises and resulted in further unrest and criticism from the ranks of the party. ${ }^{24}$

Another important ideological theme is the issue of economic liberalism. Economic programming is not one of the MHP's strengths. Perhaps because economic policy is among the weakest issues on the party's program and agenda, there is no real consensus within the party on economic liberalism or, particularly, on privatization. Immediately after the 1999 election the MHP's leading economists declared in the party's official publication that the MHP was devoted to economic liberalization and to a thorough and rapid privatization program. ${ }^{25}$ As if to contradict this declaration, the MHP appointed Enis Öksüz, known for his views against privatization, as Minister of Transportation with control over two of the most significant public enterprises-Turkish Airlines and Turkish Telecom - both at the top of the privatization list. As already noted, Öksüz's stubborn attitude against full privatization proved to be a major impediment in the much-needed legislation facilitating privatization during the economic crisis of April 2001. However, as also noted, seeing that Öksüz's attitude was seriously jeopardizing the MHP's position in the DSP-MHP-ANAP coalition government, Bahçeli finally asked for Öksüz's resignation in July 2001.

In summary, under Bahçeli's leadership, a gradual shift is taking place in party ideology, not necessarily a radical change of basic principles but still an important shift of emphasis that is most apparent in the issues of political Islam, the Kurdish question, and economic liberalism. These shifts are being met with resistance and criticism from among party ranks and supporters. As such, they reveal an unspoken divide within the partythe "academics," on the one hand, and the teskilat (party organizations) on the other. The academics are basically the current leaders of the party, including Bahçeli himself, most of whom have had experience in the educational and training branches of the party. Some - but not all-have academic degrees. On the other hand, the teşkilat refers to lower-ranking leaders who come from the party organizations, mostly Ülkü Ocakları and other activist groups. Since the latter are more directly connected to the rank and file of the party, as well as the constituents, they reflect the views 
of party circles that tend to resist the changes being implemented by Bahçeli. However, such reactions are not made public, since there is a strong sense of loyalty in the party that strives to confine all criticism to within the party circles and away from the public. ${ }^{26}$

Bahçeli is able to bridge the gap between these two groups, owing to his leadership skills which depend less on democratic means than on an ability to establish tight discipline and control over the party as well as a confident demeanor that elicits respect and loyalty within the party ranks. As mentioned above, Bahçeli was able to establish the authority of the core party leadership over the rest of the party and its organs much more tightly than Alpaslan Türkeş had ever done. During board meetings under Türkeş, matters on the agenda could be openly discussed and differences of opinion easily articulated; there is much less discussion under Bahçeli and all party members and parliamentarians are expected to fully comply with the decisions and directives of the leadership.

An example that illustrates the degree to which Bahçeli takes party discipline seriously can be found in the discharging of his close friend and associate, Ali Güngör, from the party. At the time the DSP-MHP-ANAP coalition government was about to pass the controversial General Amnesty Law in 2000, Ali Güngör made a speech that publicly criticized amnesty and placed the party in a difficult position during critical negotiations on the issue. Bahçeli did not hesitate to have him summarily discharged. Likewise, when the MHP's Minister of Agriculture, Hüsnü Yusuf Gökalp, publicly criticized Prime Minister Bülent Ecevit for incompetence and ANAP's leader Mesut Yılmaz for corruption, Bahçeli issued a written statement to all the MHP's ministers warning them not to give any public statements on issues outside of their ministry's affairs. ${ }^{27}$

\section{CONCLUSION}

The MHP has undergone a substantial evolution since it was formed in 1969. It gradually moved away from the far right to approach the center of the political spectrum, a trend that had begun in the latter years of Alpaslan Türkeş' leadership and accelerated under Devlet Bahçeli. It is this transformation that allowed the MHP to enter into a successful coalition partnership with the centrist ANAP and the center-left DSP in 1999. Thus, the MHP gradually took on the position of not a far-right but a center-right party. However, this transformation is far from being complete and is met with substantial resistance and confusion from the party and its supporters. 
The main points of contention revolve around the issues of political Islam (namely, to what degree will the MHP endorse the ban on headcovering and other restrictions on political Islam); the Kurdish question (namely, to what degree will the MHP back down on the insistence on executing PKK leader Abdullah Öcalan and the use of the death penalty in general); and the endorsement of economic liberalism (namely, to what degree will the MHP support and assist the implementation of full scale privatization in particular and the cessation of clientelist policies in general). While the party leadership takes more centrist policies on these issues, different circles of MHP sympathizers continue to express discontent with such policies and some top-ranking MHP politicians and party officials continue to act in dissension to the party's main policy lines. Despite the resistance and lack of intra-party consensus toward the party's transformation into a center-right party, the MHP leadership under Bahçeli thus far has been quite successful in meeting these challenges while maneuvering the party through a difficult coalition partnership that started in 1999. Immediately after the coalition government was formed, the MHP found itself facing some of the most difficult challenges and crises in Turkey's history. Starting with the worst natural catastrophe that Turkey ever experienced, namely the August 1999 earthquake, the DSP-MHPANAP coalition government then faced the challenge to carry Turkey into a candidacy to European Union membership and the ensuing preparations of the National Program. In 2001, the same government found itself in the midst of Turkey's worst economic crisis. Throughout these trying times, the MHP's ability to remain as a stable coalition partner and adapt itself to government policies that sometimes went against party traditions and principles has no doubt contributed to the persistence of the coalition government and the maintenance of political stability. This adaptability has not only demonstrated Devlet Bahçeli's success in leading his party through the transformation of the MHP toward a more centrist position, but also significantly contributed to the perseverance and stability of democracy in Turkey.

\section{NOTES}

1. These terms refer to ideologies that take nationalism (membership to a particular community connected by national as opposed to kinship or religious ties) as their constitutive basis, but have differing degrees of emphasis on race and ethnicity as the core defining element of the national connection. While cultural nationalism emphasizes language and shared cultural traits as the basis of the national connection, racism and ultra-nationalism take race and primordial/biological traits as their basis. The latter two forms of nationalism are also referred to as extremism in this article. For a detailed account of nationalist ideologies, see Liah 
Greenfield, Nationalism: Five Roads to Modernity (Cambridge, MA: Harvard University Press, 1992); Montserrat Guibernau and John Rex, The Ethnicity Reader: Nationalism Multiculturalism and Migration (Cambridge: Polity Press, 1997).

2. For a detailed account of the idealist militants, see Tanıl Bora, and Kemal Can, Devlet, Ocak, Dergah: 12 Eylül'den 1990'lara Ülkücü Hareket (Istanbul: İletişim Yayınları, 1994), pp.377-406.

3. This organization was the continuation of the Türkçüler Derneği (Turkists Club), which was founded in 1963 by grass-root racists, such as Nihal Atsız and İsmet Tümtürk.

4. E. Burak Arıkan, "The Programme of the Nationalist Action Party of Turkey: An Iron Hand in a Velvet Glove," Middle Eastern Studies, Vol.34, No.4 (Oct. 1998), pp.120-34.

5. For a minimum definition of fascism, see Geoffrey Harris, The Dark Side of Europe: The Extreme Right Today (Edinburgh: Edinburgh University Press, 1990), p.16.

6. For a detailed analysis of Turkish-Islamic synthesis, see Arıkan (1998), pp.120-34; Bora and Can (1994), pp.147-89.

7. Bora and Can (1994), p.54.

8. Ibid., p.46.

9. Tanıl Bora, “18 Nisan- Zifiri karanlık seçimleri: MHP ve diğerleri,” Birikim, No.121 (May 1999), p.16.

10. According to an opinion poll conducted by A \& G Research Company, the parents of 30 percent of the MHP supporters were born in central Anatolia.

11. Murat Șefkatli, Beşeri Münasebetler (Ankara: MHP Siyaset Okulu Eğitim Serisi No.5, 1999), pp. $25-30$.

12. Both of these quotes appeared in the same booklet published by the party: MHP Parti Yayınları, MHP Milli Tarım-Orman Politikalarl (Ankara: Sargın Ofset, 1999).

13. See, for example, Cumhuriyet (Istanbul daily), Nov. 8, 2000; Okay Gönensin, Yenibinyıl (Istanbul daily) Nov. 7, 2000; Șahin Alpay, Milliyet (Istanbul daily), Nov. 9, 2000; Ertuğrul Özkök, Hürriyet (Istanbul daily), Nov. 7, 2000.

14. Some of the meanings of these gestures and symbols are obscure, even to the party members themselves. For whatever reason they originated, they became the marks that distinguish followers of the ülkücü cause.

15. Burak Arıkan, "The Nationalist Action Party of Turkey: Extremists Under Transition?," typescript.

16. Hürriyet (Istanbul daily), Nov. 24, 1997. For a more detailed account, see Marvin Howe, Turkey Today: A Nation Divided Over Islam's Revival (Boulder, CO: Westview Press, 2000), pp.122-3.

17. For Aydınlar Ocağı and its influence on the MHP ideology, see Arıkan (1998).

18. A. Türkeş, Milliyetçilik (İstanbul: Hamle Basın-Yayın, 1996), p.16.

19. Milliyetçi Hareket Partisi Programı (Ankara: pamphlet produced by MHP Parti Yayınları, Nov. 5, 2000) (trans. Alev Çınar).

20. Milliyetçi Hareket Partisi, Lider Türkiye’ye Doğru: Seçim Beyannamesi, April 18, 1999, p.28.

21. Katherine Verdery, "Wither 'Nation' and 'Nationalism'?," in Gopal Balakrishnan (ed.), Mapping the Nation (New York: Verso, 1996), p.227.

22. Ibid.

23. Metin Heper, “'Başkalaşmadan’ Değișen Milliyetçi Hareket Partisi,” Türkiye Günlüğü, No.55 (March-April 1999), pp.12-23.

24. Interview with Düzgün Karadaş, Star daily MHP correspondent, April 1, 2001.

25. Emin Çarıkçı, “Türkiye'de Ekonomik Gelişmeler ve MHP’nin İktisadi Görüşleri,” Çare, Vol.1, No.3 (May 1999), pp.19-20.

26. Interview with Düzgün Karadaş, Star daily MHP correspondent, April 1, 2001.

27. Hürriyet (Istanbul daily), March 24-26, 2001. 